\title{
Electrochemical characterization of the liquid aluminium bipolar electrode for extraction of noble metals from spent catalysts
}

\section{Andrey S. Yasinskiy, Sai Krishna Padamata, Peter V. Polyakov, Dmitriy Yu. Varyukhin}

School of non-ferrous metals and materials science, Siberian federal university, Krasnoyarsk, Russia.

\begin{abstract}
Regularities of the cathodic and the anodic behaviour of aluminium on tungsten in halide melts are investigated. The study of such systems is relevant in connection with the prospects for their use as bipolar electrodes for efficient extraction of noble metals from spent petrochemical $\mathrm{Al}_{2} \mathrm{O}_{3}$-based catalysts by the electrometallurgical method with associated production of highpurity aluminium and oxygen. Stationary and non-stationary polarization curves were obtained for the reduction and the oxidation of aluminium in molten $\mathrm{NaCl}-\mathrm{KCl}+5 \mathrm{wt} . \% \mathrm{AlF}_{3}$ and $1.3 \mathrm{KF}$ $\mathrm{AlF}_{3}$ systems at $700-850{ }^{\circ} \mathrm{C}(973-1123 \mathrm{~K})$ in the range of current densities from 0.01 to 1.5 $\mathrm{A} \cdot \mathrm{cm}^{-2}$ and in the range of potential sweep rates from 0.01 to $5 \mathrm{~V} \cdot \mathrm{s}^{-1}$. Electrochemical characterization of the electrode showed that electroactive particles in chloride-based melts have higher diffusion coefficients (in comparison with fluoride melt) due to the high concentration of $\mathrm{Na}(\mathrm{I})$ and $\mathrm{K}(\mathrm{I})$ cations, low density and viscosity of the melt. Electrochemical dissolution and reduction of aluminium in both chloride-based and fluoride melts are quasi-reversible diffusioncontrolled processes complicated by several parallel phenomena. Cathodic reduction of Al(III) in both studied melts occurs at high overvoltages (more than $200 \mathrm{mV}$ at $0.1 \mathrm{~A} \cdot \mathrm{cm}^{-2}$ ) with the limiting current densities of $0.3-0.4 \mathrm{~A} \cdot \mathrm{cm}^{-2}$ at $800{ }^{\circ} \mathrm{C}$. The cathodic reduction of $\mathrm{Na}(\mathrm{I})$ starts in chloride-based melts at the potential of $-0.5-(-0.7) \mathrm{V}$ relative to Al reference electrode; the reduction of $\mathrm{K}(\mathrm{I})$ in both studied melts starts at $-1.0-(-1.2) \mathrm{V}$. In general, the kinetic parameters of the processes show that the extraction in two-sectioned cell can be beneficially performed at $800{ }^{\circ} \mathrm{C}$ with high current densities, and the liquid aluminium bipolar electrode seems to be the promising solution.
\end{abstract}

Keywords: bipolar electrode, metal refining, high-purity aluminium, platinum group metals, catalyst processing, polarization curves, kinetics of electrode processes, electrolysis of melts

\section{Introduction}

The platinum group metals (PGM), six transition metal elements with similar physical and chemical properties, play the role of catalysts in the processes of the petrochemical industry and automotive catalytic converters. The main constituents of catalysts are the carrier and the active component. Petrochemical catalysts consist of an $\mathrm{Al}_{2} \mathrm{O}_{3}$-based carrier and $0.05-1 \%$ of noble metals (PGM and rhenium) as the active components [1]. 
The catalysts gradually lose their catalytic activity during the operation. The life of catalysts varies from 3 to 5 years. The deactivated (or spent) catalysts are prohibited for disposal at landfills and require processing to extract valuable components.

A large number of pyro- [1-7] and hydrometallurgical [3, 8-11] methods of noble metals extraction from the spent catalysts were reported. Many of them are realized on an industrial scale. Common significant drawbacks of these methods often are the high cost of equipment and consumables, the high specific energy consumption and the huge amount of waste.

Belov et al. $[12,13,14]$ proposed an electrochemical method for the extraction of Pd from spent $\mathrm{Al}_{2} \mathrm{O}_{3}$-based catalysts, which was carried out in several stages, based on the HallHeroult process for the primary aluminium production and the three-layer refining process for the high-purity aluminium production. These stages are:

1. Calcination of the catalysts at $800{ }^{\circ} \mathrm{C}$ under air (or oxygen) atmosphere to remove organic impurities and partially transform PGM into oxides;

2. Dissolution of the catalysts in the molten fluoride system $\left(\mathrm{Na}_{3} \mathrm{AlF}_{6}-\mathrm{AlF}_{3}-\mathrm{CaF}_{2}\right)$, electrodeposition of aluminium and PGM on the cathode alloy with the simultaneous evolution of carbon dioxide on the carbon anode:

$$
\mathrm{Al}_{2} \mathrm{O}_{3}(\mathrm{dis})+1.5 \mathrm{C}(\mathrm{s}) \Rightarrow 2 \mathrm{Al}(\mathrm{l})+1.5 \mathrm{CO}_{2}(\mathrm{~g})
$$

3. Electrolytic refining of an Al-Cu-PGM alloy $(\mathrm{Cu}$ is added for higher density) with electrodeposition of high-purity aluminium at the cathode and concentration of PGM in the anode alloy.

This process requires high $\left(950-970{ }^{\circ} \mathrm{C}\right)$ temperature and should be operated within a narrow window of catalysts concentration to prevent the sludge formation and the emission of perfluorocarbons during low- or high-voltage anode effect that in case of slow dissolution can be a difficult problem to overcome.

Despite the mentioned considerations, several experimental facts confirm the perspectivity of the electrochemical extraction method [12-14]:

$\square$ with the introduction of palladium oxide into molten cryolite contacted by aluminium, palladium is reduced and dissolved in aluminium, while the addition of finely dispersed palladium to the melt leads to its appreciable distribution between aluminium and cryolite (in the latter, palladium forms the suspension);

$\square \quad$ palladium from the catalysts is reduced at the cathode and almost completely concentrated in primary aluminium (98-99\%);

$\square$ replacing smelter grade alumina (SGA) with the catalyst in the Hall-Heroult process has virtually no effect on the performance of the aluminium production; 
$\square \quad$ the presence of palladium in the anode alloy in the three-layer refining process has almost no effect on the current efficiency of the aluminium refining;

$\square$ high palladium extraction degree $(>98 \%)$, and the simultaneous production of high-purity aluminium (A97, A99) were achieved.

The cost of noble metals extraction from spent catalysts can be significantly reduced by using a one-step electrochemical method. Moreover, the temperature of the process can be lowered to $700-850{ }^{\circ} \mathrm{C}$ by replacing sodium cryolite with low-temperature fluoride or chloride melts with considerable solubility of $\mathrm{Al}_{2} \mathrm{O}_{3}$. The promising option, the molten $1.3 \mathrm{KF}-\mathrm{AlF}_{3}$ system has been studied elsewhere $[15,16]$. Dividing the cell into two parts (half-cells) by supported vertical or unsupported horizontal liquid Al membrane (bipolar electrode) can be a beneficial solution for one-step extraction. The first half-cell acts as the aluminium reduction cell, the second one plays the role of the aluminium refinery cell. In that case, the carbon anode can be replaced by the metallic one, which enables oxygen evolution by the reaction:

$$
\mathrm{Al}_{2} \mathrm{O}_{3}(\mathrm{dis}) \Rightarrow 2 \mathrm{Al}(\mathrm{l})+1.5 \mathrm{O}_{2}(\mathrm{~g})
$$

More details on this technology are given in patent [17]. The process can obviously be implemented for aluminium reduction with oxygen-evolving anodes simply by using alumina instead of spent catalysts. In that case, the liquid bipolar electrode will be used to collect the anode corrosion products that sounds beneficial because the proper cathode metal purity remains one of the most difficult and important tasks in the inert anode research. However, due to economic reasons having platinum-reach alloy as a product provides a wider window for the cell voltage, current efficiency and specific energy consumption in comparison with having only high-purity aluminium that makes the advisability of this technology for aluminium production questionable. On the other hand, we believe this technology to be a good subject for further development, and attempts to make it meet the energy efficiency requirements of aluminium industry does not seem meaningless due to drastic ecological effect. In particular, the following improvements can make this process being applicable for aluminium production:

$\square \quad$ a decrease in interelectrode spaces especially in the refinery half-cell;

$\square \quad$ an increase in alumina dissolution rate in low-temperature electrolytes;

$\square \quad$ a decrease in diffusion overvoltages by the decrease in current densities;

$\square$ design of the continuous alumina feeding system.

The electrochemical characterization of the metallic anode is studied and reported elsewhere $[18,19]$. This work deals with the electrochemical study of dissolution and electrodeposition of aluminium on the liquid bipolar electrode in chloride (more likely to be used in refinery half-cell) and low-temperature fluoride melts. The results of this study supplement 
scarce data on the kinetics of aluminium deposition and oxidation in chloride-based and fluoride melts at $700-850{ }^{\circ} \mathrm{C}$.

Performance of the Al(III)/Al electrode studied in chloride [20, 21] and fluoride [22-23, 24] melts and reported in recent works with more attention to the cathodic process of Al(III) or $\mathrm{Al}(\mathrm{I})$ reduction. Deposition of $\mathrm{Al}$ on tungsten first leads to a formation of intermetallic compound $\mathrm{Al}_{4} \mathrm{~W}$ [24]. In $\mathrm{AlCl}_{3}-\mathrm{NaCl}$ melts the cathodic process is believed [21] to consist of two consecutive steps:

$$
\begin{aligned}
& 4 \mathrm{Al}_{2} \mathrm{Cl}_{7}{ }^{-}+3 e^{-} \Rightarrow \mathrm{Al}+7 \mathrm{AlCl}_{4}{ }^{-} \\
& \mathrm{AlCl}_{4}{ }^{-}+3 e^{-} \Rightarrow \mathrm{Al}+4 \mathrm{Cl}^{-}
\end{aligned}
$$

Deposition of $\mathrm{Al}$ in fluoride melts involves both three-electron and two electrons reactions [24]:

$$
\begin{aligned}
& A l F_{4}{ }^{-}+3 e^{-} \Rightarrow A l+4 F^{-} \\
& A l F_{4}{ }^{-}+2 e^{-} \Rightarrow A l F_{2}{ }^{-}+2 F^{-}
\end{aligned}
$$

Other researchers $[16,25]$ reported different cathodic mechanisms involving $\mathrm{AlF}_{5}^{2-}$, $\mathrm{AlF}_{6}{ }^{3-}$ and, if oxygen ions are introduced to the melt, $\mathrm{Al}_{2} \mathrm{OF}_{6}{ }^{2-}$ and $\mathrm{Al}_{2} \mathrm{O}_{2} \mathrm{~F}_{4}{ }^{2-}$. The diffusion coefficients of these electroactive particles in studied fluoride melt were reported to be in the wide range of $10^{-7}[24]-10^{-4} \mathrm{~cm}^{2} \cdot \mathrm{s}^{-1}[26]$. There is also a disagreement of different points of view on the ionic structure of both molten fluoride and chloride melts and electrode processes as well. This research contributes more experimental data for the understanding of electrode processes kinetics and estimates the diffusion coefficients of electroactive particles.

\section{Experimental}

Electrolytes were synthesized at $900{ }^{\circ} \mathrm{C}$ from the dried individual chemically pure (p.a.) salts $\mathrm{NaCl}, \mathrm{KCl}, \mathrm{KF}$ and $\mathrm{AlF}_{3}$. Drying lasted for 4 hours at $400{ }^{\circ} \mathrm{C}$. The prepared melt was purified with the electrolysis during $2 \mathrm{~h}$ with a graphite cathode under the potential of $0.2 \mathrm{~V}$ relative to the aluminium electrode potential.

The electrochemical measurements were carried out in a three-electrode graphite cell under air atmosphere in the temperature range of $700-850^{\circ} \mathrm{C}$. The graphite crucible served as an auxiliary (counter) electrode. Tungsten rod with a diameter of $5 \mathrm{~mm}$ placed into a BN tube was used as a working electrode. The working electrode potential was measured with respect to the potential of the aluminium reference electrode encapsulated into a BN case. The cell was heated by the vertical electric furnace. The temperature of the electrolyte was measured by the k-type thermocouple in a $\mathrm{BN}$ case connected to the controller and maintained constant $\left( \pm 2^{\circ} \mathrm{C}\right)$. The current and the potential were supplied or measured using AutoLab PGSTAT 302n and NOVA 2.1 Software (The MetrOhm, Netherlands). 
Cyclic voltammograms were obtained at different potential sweep rates in the range 0.01 $-5 \mathrm{~V} \cdot \mathrm{s}^{-1}$. The ohmic voltage drop of the measuring circuit was determined by the current interrupt technique and compensated during the sweep. The stationary polarization dependencies were determined by recording the steady-state value of the electrode potential at different cathodic current densities in the range of $0.01-1.5 \mathrm{~A} \cdot \mathrm{cm}^{-2}$.

\section{Results and discussion}

\section{Voltammetry}

The characterization of aluminium bipolar electrode involves the cathodic deposition of $\mathrm{Al}$ on wettable (tungsten) electrode in $1.3 \mathrm{KF}-\mathrm{AlF}_{3}$ melt and the anodic dissolution of aluminium in $\mathrm{NaCl}-\mathrm{KCl}+5 \mathrm{wt} . \% \mathrm{AlF}_{3}$ melt. The deposition in the chloride-based melts is also of particular interest as it happens on the high-purity aluminium cathode in the refinery half-cell. Cyclic voltammograms recorded on tungsten in chloride-based melts at $700-850{ }^{\circ} \mathrm{C}$ with different sweep rates in a range of $10-1000 \mathrm{mV} \cdot \mathrm{s}^{-1}$ are presented in Fig. 1.
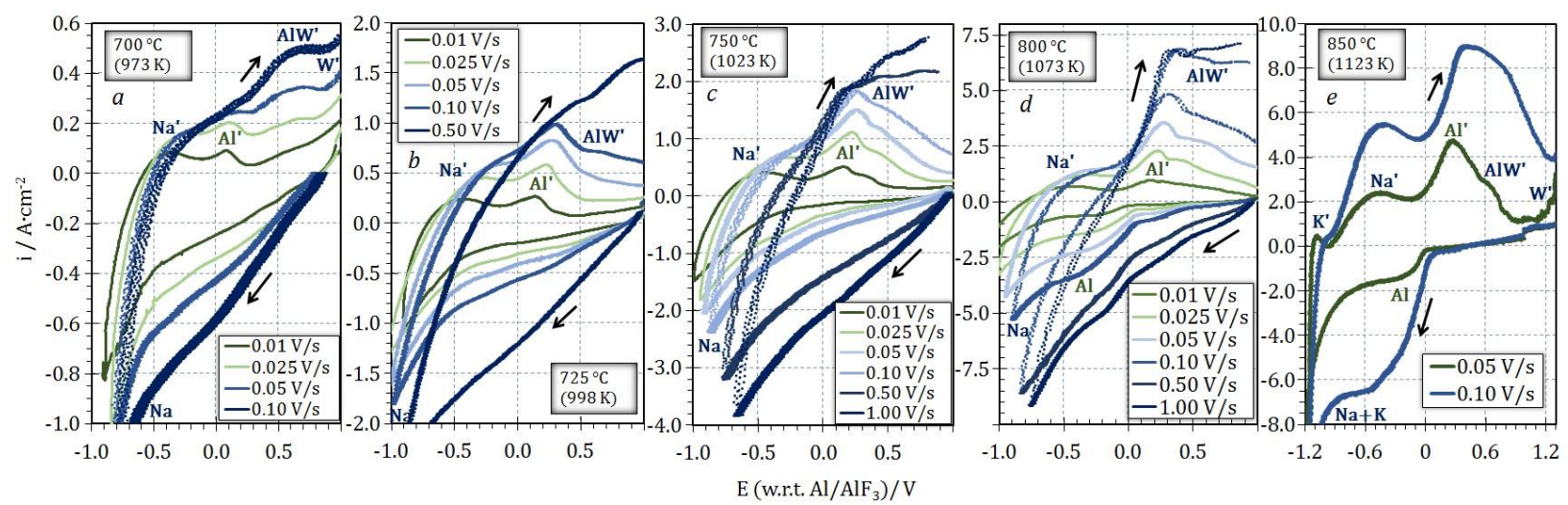

Fig 1 - Cyclic voltammograms recorded on tungsten in $\mathrm{NaCl}-\mathrm{KCl}+5 \mathrm{wt} . \% \mathrm{AlF}_{3}$ melt with various sweep rates of $10-1000 \mathrm{mV} \cdot \mathrm{s}^{-1}$ at: $\mathrm{a}-973 \mathrm{~K}$; b-998 K; c $1023 \mathrm{~K}$; d $-1073 \mathrm{~K}$; e-1123 K

It can be observed on the cyclic voltammograms at high temperatures $\left(800\right.$ and $\left.850{ }^{\circ} \mathrm{C}\right)$, that aluminium starts to be deposited at potentials more negative than $+0.05 \mathrm{~V}$. At lower temperatures different reduction process increased the current density and changed the baseline for the aluminium electrode. This process can be associated with the presence of B(III), W(IV), W(VI), C (II), C(IV) cations, etc. Standard reversible potentials for B/B(III) and W/W(IV) at 800 ${ }^{\circ} \mathrm{C}$ are 0.58 and $1.33 \mathrm{~V}$ relative to $\mathrm{Al}(\mathrm{III}) / \mathrm{Al}$ reference electrode. The values of measured reversible potentials were in the range of $0.4-1.0 \mathrm{~V}$ that supports this idea. These cations are introduced by the cell parts. The cathodic peak current densities were recorded at potentials from -0.2 to $-0.4 \mathrm{~V}$. In the case if the peaks were not visible due to the background reduction process it was determined at the potential when the slope of the curve appreciably decreased. In other 
cases (at $700{ }^{\circ} \mathrm{C}$ with $10 \mathrm{mV} \cdot \mathrm{s}^{-1}$ sweep rate) the slope change was not visible, so the increase in current due to the sodium reduction, which happened at potentials from -0.5 to $-0.7 \mathrm{~V}$, was considered as a peak potential for further calculations.

In the anodic part of the curves several peaks are clearly visible: oxidation peak of $\mathrm{Na}$ at the potentials from -0.4 to $-0.5 \mathrm{~V}$, oxidation peak of $\mathrm{Al}$ at the potentials from 0.2 to $0.6 \mathrm{~V}$ and another peak (much more sensitive to the sweep rate) probably associated with the oxidation of aluminium from $\mathrm{Al}_{4} \mathrm{~W}$ intermetallic compound with a sufficient shift of the peak potential to more positive values. The shift of peak potentials with respect to the sweep rate indicates that both oxidation and reduction of aluminium are quasi-reversible diffusion-controlled processes complicated by several phenomena. The peak current densities drastically increase with temperature. The temperature of $800{ }^{\circ} \mathrm{C}$ has been chosen as an optimal value for further study in the $1.3 \mathrm{KF}-\mathrm{AlF}_{3}$ melt. Cryolite ratio $\left(\mathrm{CR}=[\mathrm{KF}] /\left[\mathrm{AlF}_{3}\right]=1.3\right)$ has been chosen according to the results of previous work [26].

Cyclic voltammograms recorded on tungsten in $1.3 \mathrm{KF}-\mathrm{AlF}_{3}$ melts at 800 with different sweep rates in a range of $25-5000 \mathrm{mV} \cdot \mathrm{s}^{-1}$ are given in Fig. 2.

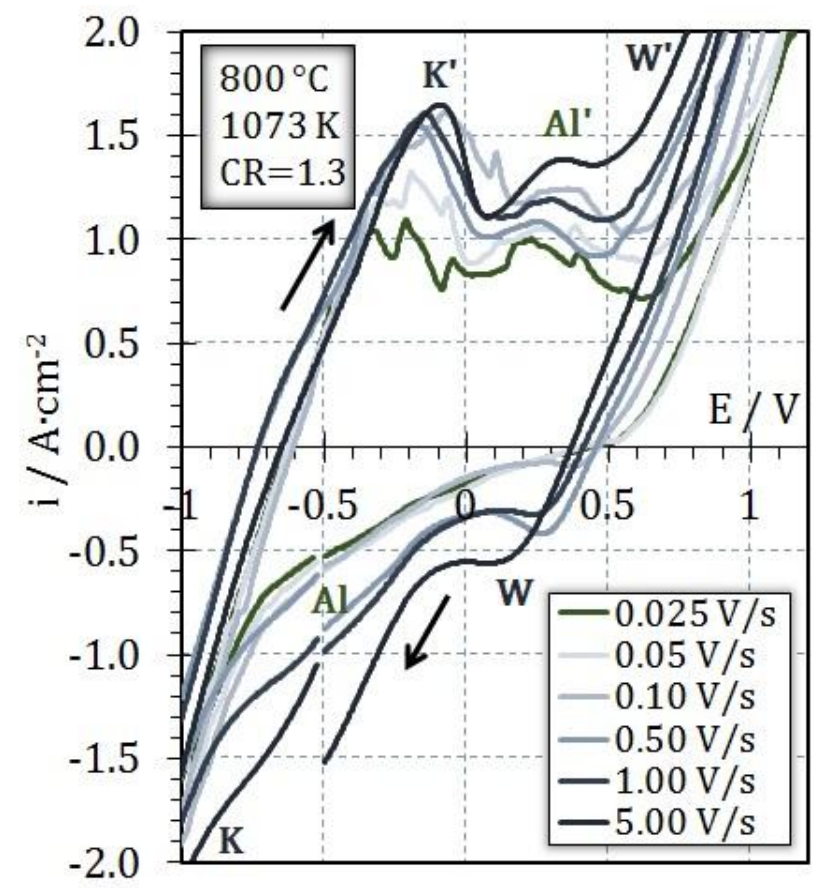

Fig 2 - Cyclic voltammograms recorded on tungsten in the $1.3 \mathrm{KF}-\mathrm{AlF}_{3}$ melt with various sweep rates of $25-5000 \mathrm{mV} \cdot \mathrm{s}^{-1}$ at $1073 \mathrm{~K}$

In the $1.3 \mathrm{KF}-\mathrm{AlF}_{3}$ melt reduction of aluminium starts at more negative potentials than in chloride-based melts $(-0.1 \mathrm{~V}$ and more negative). The values are in good agreement with the previous results [22]. The peaks of the aluminium reduction process are not visible due to the background process but can be estimated with respect to the slope change before the wave of 
potassium evolution. On the anodic part of the curve potassium oxidation peaks appear at the potentials around $-0.15 \mathrm{~V}$ and do not depend on the sweep rate when the rate is $500 \mathrm{mV} \cdot \mathrm{s}^{-1}$ and higher. Aluminium oxidation peaks appear at the potentials around $300 \mathrm{mV}$ and then are followed by the tungsten oxidation wave.

The diffusion coefficients $D$ of electroactive particles were roughly estimated with the Randles-Sevcik equation for reversible and quasi-reversible diffusion-controlled processes:

$$
i_{p}=-0.4463(z F)^{\frac{3}{2}} C\left(\frac{v D}{R T}\right)^{1 / 2}
$$

where $i_{p}$ is the peak current density, $F$ is the Faraday constant, $F=96487 \mathrm{C} \cdot \mathrm{mole}^{-1}, z$ is the number of electrons, $C$ is the concentration of electroactive particles, $v$ is the sweep rate, $R$ is the gas constant, $R=8.314 \mathrm{~J} \cdot \mathrm{mole}^{-1} \cdot \mathrm{K}^{-1}, T$ is the temperature. For the correction of a baseline for the anodic peak current density $i_{p a}$ the ratio was calculated from the uncorrected anodic peak current, $\left(i_{p a}\right)_{0}$, with respect to the zero current baseline and the current $\left(i_{s p}\right)_{0}$ at the potential of sweep direction change by Nicholson equation:

$$
\frac{i_{p a}}{i_{p c}}=\frac{\left(i_{p a}\right)_{0}}{i_{p c}}+\frac{0.485 \xi \dot{p})_{0}}{i_{p c}}+0.086
$$

The anodic and the cathodic peak current densities and the corresponded potentials $E_{p}$ are presented in Table 1 with respect to the potential sweep rate.

Table 1. Kinetic parameters of the aluminium cathodic reduction and anodic oxidation in $\mathrm{NaCl}-$

\begin{tabular}{|c|c|c|c|c|c|}
\hline \multirow{2}{*}{$v, \mathrm{~V} \cdot \mathrm{s}^{-1}$} & \multirow{2}{*}{$v^{1 / 2},\left(\mathrm{~V} \cdot \mathrm{s}^{-1}\right)^{1 / 2}$} & \multicolumn{2}{|c|}{ anodic } & \multicolumn{2}{|c|}{ cathodic } \\
\hline & & $\mathrm{i}_{\mathrm{p}}, \mathrm{A} \cdot \mathrm{cm}^{-2}$ & $\mathrm{E}_{\mathrm{p}}, \mathrm{V}$ & $\left|\mathrm{i}_{\mathrm{p}}\right|, \mathrm{A} \cdot \mathrm{cm}^{-2}$ & $\mathrm{E}_{\mathrm{p}}, \mathrm{V}$ \\
\hline \multicolumn{6}{|c|}{$\mathrm{NaCl}-\mathrm{KCl}+5 \mathrm{wt} . \% \mathrm{AlF}_{3} 700{ }^{\circ} \mathrm{C}(973 \mathrm{~K})$} \\
\hline 0.01 & 0.10 & 0.09 & 0.13 & 0.39 & -0.49 \\
\hline 0.025 & 0.16 & 0.20 & 0.15 & 0.50 & -0.48 \\
\hline 0.05 & 0.22 & 0.25 & 0.14 & 0.63 & -0.58 \\
\hline 0.10 & 0.32 & 0.29 & 0.15 & 0.85 & -0.60 \\
\hline 0.50 & 0.71 & $\mathrm{n} / \mathrm{v}^{*}$ & $\mathrm{n} / \mathrm{v}$ & 1.40 & -0.50 \\
\hline 1.00 & 1.00 & $\mathrm{n} / \mathrm{v}$ & $\mathrm{n} / \mathrm{v}$ & 1.60 & -0.50 \\
\hline \multicolumn{6}{|c|}{$\mathrm{NaCl}-\mathrm{KCl}+5 \mathrm{wt} . \% \mathrm{AlF}_{3} 725^{\circ} \mathrm{C}(998 \mathrm{~K})$} \\
\hline 0.01 & 0.10 & 0.26 & 0.14 & 0.22 & -0.25 \\
\hline 0.025 & 0.16 & 0.58 & 0.20 & 0.38 & -0.40 \\
\hline 0.05 & 0.22 & 0.82 & 0.25 & 0.55 & -0.30 \\
\hline 0.10 & 0.32 & 0.98 & 0.40 & 0.80 & -0.45 \\
\hline 0.50 & 0.71 & 1.24 & 0.39 & 1.70 & -0.50 \\
\hline \multicolumn{6}{|c|}{$\mathrm{NaCl}-\mathrm{KCl}+5 \mathrm{wt} . \% \mathrm{AlF}_{3} 750^{\circ} \mathrm{C}(1023 \mathrm{~K})$} \\
\hline 0.01 & 0.10 & 0.42 & 0.19 & 0.22 & -0.25 \\
\hline 0.025 & 0.16 & 0.51 & 0.25 & 0.81 & -0.26 \\
\hline 0.05 & 0.22 & 1.12 & 0.30 & 1.02 & -0.36 \\
\hline 0.10 & 0.32 & 1.50 & 0.29 & 1.41 & -0.28 \\
\hline 0.50 & 0.71 & 1.83 & 0.18 & $\mathrm{n} / \mathrm{v}$ & $\mathrm{n} / \mathrm{v}$ \\
\hline 1.00 & 1.00 & 2.10 & 0.18 & $\mathrm{n} / \mathrm{v}$ & $\mathrm{n} / \mathrm{v}$ \\
\hline
\end{tabular}
$\mathrm{KCl}+5 \mathrm{wt} . \% \mathrm{AlF}_{3}$ and $1.3 \mathrm{KF}-\mathrm{AlF}_{3}$ melts at $700-850{ }^{\circ} \mathrm{C}(973-1123 \mathrm{~K})$ 


\begin{tabular}{|c|c|c|c|c|c|}
\hline 5.00 & 2.24 & 2.50 & 0.18 & $\mathrm{n} / \mathrm{v}$ & $\mathrm{n} / \mathrm{v}$ \\
\hline \multicolumn{6}{|c|}{$\mathrm{NaCl}-\mathrm{KCl}+5 \mathrm{wt} . \% \mathrm{AlF}_{3} 800^{\circ} \mathrm{C}(1073 \mathrm{~K})$} \\
\hline 0.01 & 0.10 & 0.80 & 0.21 & 0.65 & -0.21 \\
\hline 0.025 & 0.16 & 1.01 & 0.26 & 1.50 & -0.25 \\
\hline 0.05 & 0.22 & 2.30 & 0.31 & 2.35 & -0.39 \\
\hline 0.10 & 0.32 & 3.55 & 0.35 & 3.60 & -0.35 \\
\hline 0.50 & 0.71 & 4.87 & 0.39 & $\mathrm{n} / \mathrm{v}$ & $\mathrm{n} / \mathrm{v}$ \\
\hline 1.00 & 1.00 & 6.90 & 0.36 & $\mathrm{n} / \mathrm{v}$ & $\mathrm{n} / \mathrm{v}$ \\
\hline 5.00 & 2.24 & 6.85 & 0.37 & $\mathrm{n} / \mathrm{v}$ & $\mathrm{n} / \mathrm{v}$ \\
\hline \multicolumn{6}{|c|}{$\mathrm{NaCl}-\mathrm{KCl}+5 \mathrm{wt} . \% \mathrm{AlF}_{3} 850^{\circ} \mathrm{C}(1123 \mathrm{~K})$} \\
\hline 0.01 & 0.10 & 5.60 & 0.31 & 1.10 & -0.29 \\
\hline 0.025 & 0.16 & 5.90 & 0.33 & 4.50 & -0.31 \\
\hline 0.05 & 0.22 & 5.00 & 0.34 & 1.50 & -0.32 \\
\hline 0.10 & 0.32 & 9.00 & 0.38 & 6.60 & -0.49 \\
\hline 0.50 & 0.71 & 20.00 & 0.34 & $\mathrm{n} / \mathrm{v}$ & $\mathrm{n} / \mathrm{v}$ \\
\hline 1.00 & 1.00 & 19.50 & 0.35 & $\mathrm{n} / \mathrm{v}$ & $\mathrm{n} / \mathrm{v}$ \\
\hline 5.00 & 2.24 & 22.00 & 0.35 & $\mathrm{n} / \mathrm{v}$ & $\mathrm{n} / \mathrm{v}$ \\
\hline \multicolumn{6}{|c|}{$1.3 \mathrm{KF}-\mathrm{AlF}_{3} 800^{\circ} \mathrm{C}(1073 \mathrm{~K})$} \\
\hline 0.01 & 0.10 & $\mathrm{n} / \mathrm{v}$ & $\mathrm{n} / \mathrm{v}$ & $\mathrm{n} / \mathrm{v}$ & $\mathrm{n} / \mathrm{v}$ \\
\hline 0.025 & 0.16 & 0.98 & 0.21 & 0.72 & -0.58 \\
\hline 0.05 & 0.22 & 1.07 & 0.22 & 0.80 & -0.59 \\
\hline 0.10 & 0.32 & $\mathrm{n} / \mathrm{v}$ & $\mathrm{n} / \mathrm{v}$ & 0.85 & -0.58 \\
\hline 0.50 & 0.71 & 1.09 & 0.23 & 0.95 & -0.54 \\
\hline 1.00 & 1.00 & 1.19 & 0.25 & 1.21 & -0.62 \\
\hline 5.00 & 2.24 & 1.40 & 0.29 & 1.79 & -0.64 \\
\hline
\end{tabular}

*n/v denotes "not visible"

The peak current densities for anodic and cathodic processes drastically differ from each other under the same conditions. The reduction of aluminium in $1.3 \mathrm{KF}-\mathrm{AlF}_{3}$ and its oxidation in the $\mathrm{NaCl}-\mathrm{KCl}+5 \mathrm{wt} . \% \mathrm{AlF}_{3}$ melts have dramatically different kinetics parameters that can result in high overvoltages during the performance of the bipolar electrode.

The dependencies of peak current densities against the square root of the potential sweep rate for anodic and cathodic processes in the $\mathrm{NaCl}-\mathrm{KCl}+5 \mathrm{wt} . \% \mathrm{AlF}_{3}$ melt at $700-850{ }^{\circ} \mathrm{C}$ and in $\mathrm{KF}-\mathrm{AlF}_{3}$ melt at $800{ }^{\circ} \mathrm{C}$ are presented in Fig. 3.

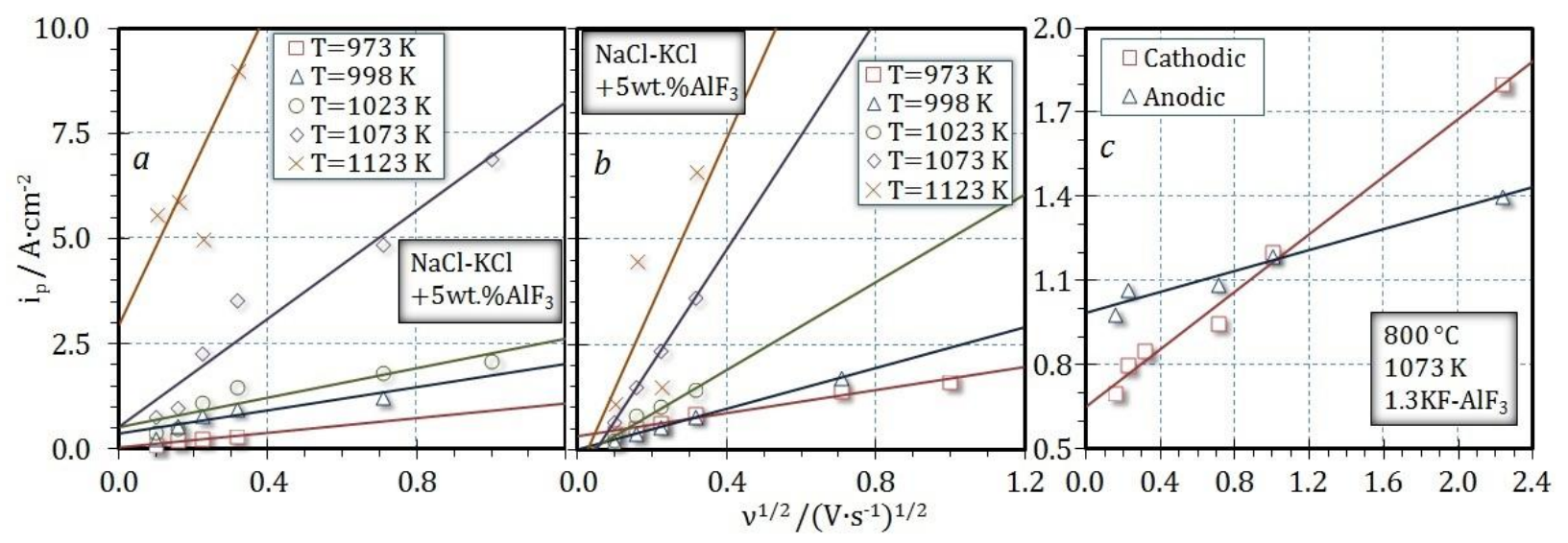


Fig 3 - Dependence of cathodic and anodic peak current densities vs. the square root of sweep rate for aluminium oxidation $(a)$ and deposition $(b)$ on tungsten substrate in $\mathrm{NaCl}-$

$\mathrm{KCl}+5 \mathrm{wt} . \% \mathrm{AlF}_{3}$ and $1.3 \mathrm{KF}-\mathrm{AlF}_{3}(c)$ melts at $700-850{ }^{\circ} \mathrm{C}(973-1123 \mathrm{~K})$

Relationships between the current peaks (true or apparent) and the square roots of sweep rates are generally linear which confirms that both oxidation and reduction processes in chloridebased melts are quasi-reversible diffusion-controlled. The dependence in $1.3 \mathrm{KF}-\mathrm{AlF}_{3}$ melt appears not to be linear in the range of very low sweep rates because the equation (7) predicts zero peak current density at zero sweep rate. That can be the result of the background processes of other cations discharge.

The densities of the melts, the concentrations and the diffusion coefficients calculated according to the eq. (7) for electroactive particles in both chloride-based and fluoride melts at $700-850{ }^{\circ} \mathrm{C}$ are presented in Table 2 . The density was calculated according to the expressions given in [29] and [26]. It was assumed that each electroactive complex ion that can be discharged at the electrode contain single $\mathrm{Al}(\mathrm{III})$ ion that can be true for oxygen-free fluoride melts. However, it can introduce some error to the concentration values in chloride melt due to the presence of $\mathrm{Al}_{2} \mathrm{Cl}_{7}$ ions. $\mathrm{Al}(\mathrm{I})$ cations were not taken into account for the calculation.

Table 2. Diffusion coefficients (D.10 $/ \mathrm{cm}^{2} \cdot \mathrm{s}^{-1}$ ) of electroactive ions $\mathrm{Al}(\mathrm{III})$ in $\mathrm{NaCl}-$ $\mathrm{KCl}+5 \mathrm{wt} . \% \mathrm{AlF}_{3}$ and $1.3 \mathrm{KF}-\mathrm{AlF}_{3}$ melts at $700-850{ }^{\circ} \mathrm{C}$

\begin{tabular}{|c|c|c|c|c|c|}
\hline \multirow{2}{*}{ Electrolyte } & \multirow{2}{*}{$\mathrm{T}, \mathrm{K}$} & \multirow{2}{*}{$\begin{array}{l}\mathrm{C}_{\mathrm{Al}(\mathrm{III})} \cdot 10^{3} \\
\text { mole } \cdot \mathrm{cm}^{-3}\end{array}$} & \multirow{2}{*}{$\begin{array}{l}\rho \cdot 10^{-4} \\
\mathrm{~kg} \cdot \mathrm{m}^{-3}\end{array}$} & \multicolumn{2}{|c|}{$\mathrm{D} \cdot 10^{5} \mathrm{~cm}^{2} \cdot \mathrm{s}^{-1}$} \\
\hline & & & & Oxidation & Reduction \\
\hline \multirow{4}{*}{ NaCl-KCl-5wt.\% $\% \mathrm{AlF}_{3}$} & 973 & 0.899 & 1.573 & $0.23 \pm 0.08$ & $1.12 \pm 0.54$ \\
\hline & 998 & 0.894 & 1.565 & $1.99 \pm 0.96$ & $1.24 \pm 0.12$ \\
\hline & 1023 & 0.886 & 1.550 & $2.77 \pm 1.70$ & $4.88 \pm 0.75$ \\
\hline & 1073 & 0.870 & 1.522 & $10.18 \pm 4.90$ & $19.75 \pm 8.54$ \\
\hline $1.3 \mathrm{KF}-\mathrm{AlF}_{3}$ & 1073 & 9.006 & 1.740 & $0.04 \pm 0.04$ & $0.02 \pm 0.02$ \\
\hline
\end{tabular}

The diffusion coefficients dramatically increase with the temperature. The values estimated for the cathodic process in chloride melts are naturally higher than those for the anodic dissolution. The reason is probably associated with different diffusing electroactive particles. It seems that the electrode process mechanism connected with one of the equilibriums (3) and (4) where the particles in the left side are naturally larger and should be less mobile than those in the right side can be questionable. Other possible mechanisms of aluminium oxidation can be considered:

$$
\mathrm{Al}_{2} \mathrm{Cl}_{7}^{-}+5 \mathrm{Cl}^{-}+\mathrm{Al} \Rightarrow 3 \mathrm{AlCl}_{4}^{-}+3 \mathrm{e}^{-}
$$


Lower diffusion coefficients in fluoride melt are associated with higher density and viscosity of the melt due to the presence and the high concentration of large complex ions and the low concentration of $\mathrm{Na}(\mathrm{I})$ and $\mathrm{K}(\mathrm{I})$ cations.

The diffusion coefficients in chloride-based melts at $850{ }^{\circ} \mathrm{C}$ had rather high values $\left(10^{-3}\right.$ $\mathrm{cm}^{2} \cdot \mathrm{s}^{-1}$ and more) that require further research and explanation or the finding of the experimental inaccuracy.

\section{Stationary polarization}

It seems that noble metals can be extracted from spent catalysts at the temperatures not less than $800{ }^{\circ} \mathrm{C}$ because of diffusion difficulties in the fluoride melts. For further characterization of $\mathrm{Al}$ bipolar electrodes potentials and overvoltages for stationary galvanostatic polarization curves (Fig. 4) were found according to the equations:

$$
\begin{aligned}
& U=E_{\text {rev }}+\eta_{a}+\eta_{c}+I R \\
& E_{c}=E_{\text {rev }}-\eta_{c}
\end{aligned}
$$

where $U$ is the cell voltage, $E_{\text {rev }}$ is the reversible potential or EMF (with respect to the reference electrode), $\eta_{c}$ is the cathodic overvoltage (overpotential), $I R$ is the Ohmic voltage drop, determined by current interrupt technique. The relation between the overvoltage and the current density for certain kinds of electrode processes (if the diffusion of reduced form can be neglected) is governed by the equation:

$$
\eta=-\frac{R T}{z F} \cdot \ln \left(1-\frac{i}{i_{l}}\right)
$$

where $i$ is the current density, $i_{l}$ is the limiting current density given as a function of mass transfer coefficient $K_{S}=D / \delta$ (where $\delta$ is the diffusion layer thickness) and $C$ :

$$
i_{l}=z \cdot F \cdot K_{s} \cdot C
$$

Galvanostatic polarization curves for both chloride-based and fluoride melts at $800{ }^{\circ} \mathrm{C}$ were placed on the same graph (Fig. 4b). 


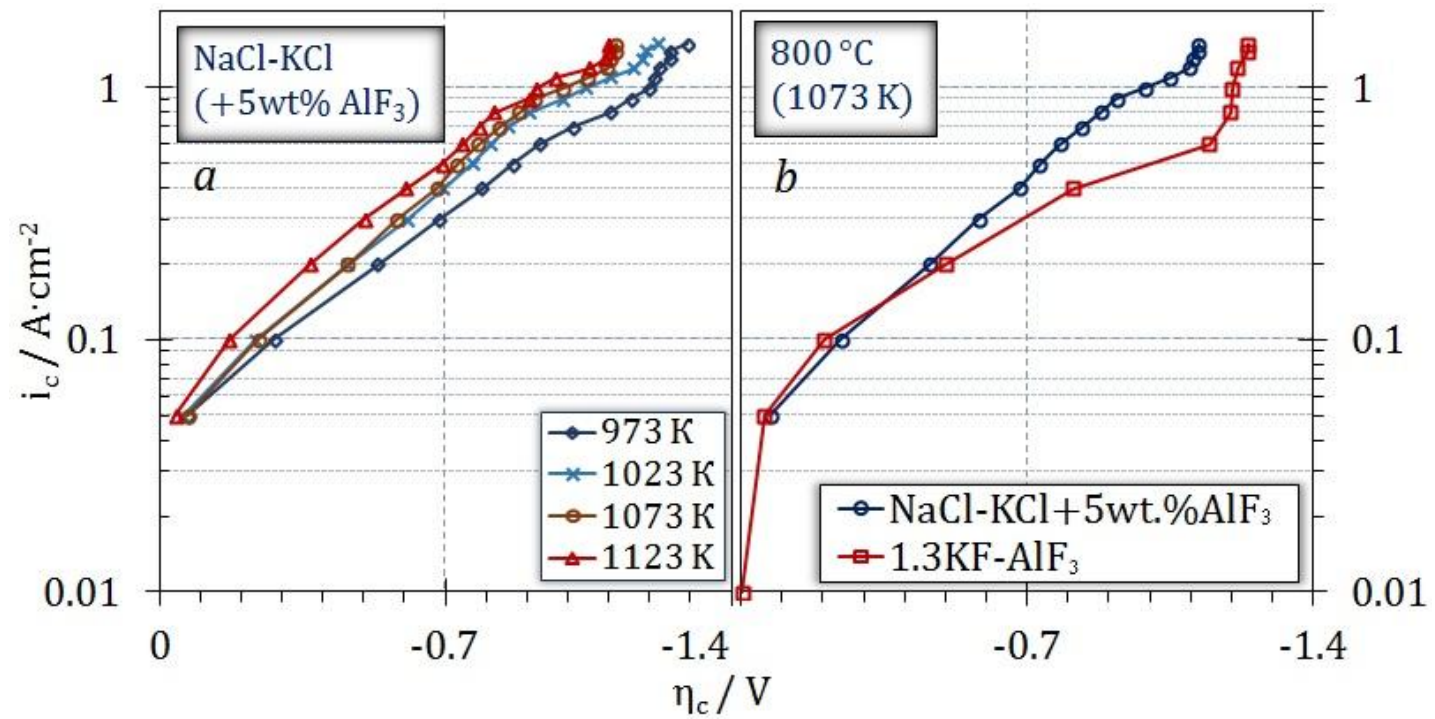

Fig 4 - Stationary polarization curves for cathodic reduction of aluminium on tungsten substrate in $\mathrm{NaCl}-\mathrm{KCl}+5 \mathrm{wt} . \% \mathrm{AlF}_{3}$ and $1.3 \mathrm{KF}-\mathrm{AlF}_{3}$ melts at $973-1123 \mathrm{~K}$

The cathodic process in both chloride-based and fluoride melts has a significant overvoltage within a wide range of current densities. The overvoltage naturally decreases with the temperature. In both studied melts limiting current densities of $0.3-0.4 \mathrm{~A} \cdot \mathrm{cm}^{-1}$ appear at the overvoltages of around $0.6-0.8 \mathrm{~V}$. The cathodic reduction of $\mathrm{Na}(\mathrm{I})$ starts in chloride-based melts at the potential of $-0.5-(-0.7) \mathrm{V}$; the reduction of $\mathrm{K}(\mathrm{I})$ in both studied melts starts at -1.0 - (-1.2) V. In chloride-based melts the overvoltage of aluminium reduction is lower at the same $\mathrm{T}$ due to the high diffusion coefficients of electroactive particles.

It is briefly described earlier [22] that cathodic process is complicated by several parallel phenomena: a discharge of aluminium from different ionic forms, salt passivation, an appearance of dissolved aluminium near the cathode layer and rapid consumption of aluminium by the secondary process. This idea is supported by several experimental observations made in the current work:

$\square$ both anodic and cathodic process in some certain cases has double or triple peaks that can indicate the discharge of different particles;

$\square$ several limiting currents appear on the galvanostatic cathodic polarization curves in some cases;

$\square \quad$ the peak potentials depend on the sweep rate that indicates the quasi-reversible process.

These "certain cases" are not clear yet and require further research for a deeper understanding of the anodic and the cathodic processes on Al electrode in chloride-based and fluoride melts.

\section{Conclusion}


The liquid aluminium bipolar electrode seems to be the promising solution for the electrochemical extraction of noble metals from spent $\mathrm{Al}_{2} \mathrm{O}_{3}$-based catalysts in halide melts. The electrochemical characterization of the electrode showed that:

$\square$ electroactive particles in chloride-based melts have higher diffusion coefficients (in comparison with $1.3 \mathrm{KF}-\mathrm{AlF}_{3}$ melt) due to the high concentration of $\mathrm{Na}(\mathrm{I})$ and $\mathrm{K}(\mathrm{I})$ cations, low density and viscosity of the melt;

$\square$ electrochemical dissolution and reduction of aluminium in both chloride-based and fluoride melts are quasi-reversible diffusion-controlled processes complicated by several parallel phenomena;

$\square \quad$ cathodic process in chloride-based melts requires the delivery of more mobile particles than the anodic dissolution of aluminium that make questionable the mechanism of discharge of $\mathrm{Al}(\mathrm{III})$ cations and ionization of $\mathrm{Al}(0)$;

$\square$ cathodic reduction of $\mathrm{Al}(\mathrm{III})$ in both $\mathrm{NaCl}-\mathrm{KCl}+5 \mathrm{wt} . \% \mathrm{AlF}_{3}$ and $1.3 \mathrm{KF}-\mathrm{AlF}_{3}$ melts occurs at high overvoltages (more than $200 \mathrm{mV}$ at $0.1 \mathrm{~A} \cdot \mathrm{cm}^{-2}$ ) with the limiting current densities of $0.3-0.4 \mathrm{~A} \cdot \mathrm{cm}^{-2}$ at $800{ }^{\circ} \mathrm{C}$;

$\square$ according to the stationary polarization curves, the cathodic reduction of $\mathrm{Na}(\mathrm{I})$ in chloridebased melts starts at the potential of $-0.5-(-0.7) \mathrm{V}$; the reduction of $\mathrm{K}(\mathrm{I})$ in both studied melts starts at $-1.0-(-1.2) \mathrm{V}$.

In general, the kinetic parameters of the processes on the bipolar electrode show that the extraction in the two-sectioned cell can be beneficially performed at $800{ }^{\circ} \mathrm{C}$ with the high current densities. However, further study is required to establish the effects of catalyst content on kinetics and dissolution rate and to solve other relevant problems.

\section{Acknowledgements}

The reported study was funded by RFBR according to the research project № 18-2924122.

\section{References}

1. Akcil A., Vegliò F., Ferella F., Okudan M.D., Tuncuk A. A review of metal recovery from spent petroleum catalysts and ash. Waste Management. 2015, 45, pp. 420-433.

2. $\quad$ Peng Z., Li Z., Lin X., Tang H., Ye L., Ma Yu., Rao M., Zhang Y., Li G., Jiang T. Pyrometallurgical recovery of platinum group metals from catalysts. JOM. 2017, 69 (9) pp. $1553-1562$. 
3. Ding Y., Zhang S., Liu B., Chang C.-C., Ekberg C., Recovery of precious metals from electronic waste and spent catalysts: A review. Resources, Conservation and Recycling. 2019, February, pp. 284-298.

4. Kolliopoulos G., Balomenos E., Giannopoulou L., Yakoumis I., Panias D. Behavior of Platinum Group Metals during Their Pyrometallurgical Recovery from Spent Automotive Catalysts. Open Access Library Journal. 2014, 1, pp. 1-9.

5. Liu C., Sun S.C., Zhu X.P., Tu G.F., Zhang J.Y. Recovery of platinum from the spent auto-catalysts by pyrometallurgy. IOP Conf. Materials Science and Engineering. 2019, 479 012058 .

6. Fujima K., Morimoto T., Itoigawa H., Becchaku D. Development of a Process for Recycling Platinum Group Metals Using Molten Alkali Metal Chlorides. Journal of the Japan Institute of Metals and Materials. 2017, 81 (4) pp. 168-177.

7. You, G., Fang W., Li Q., Ma Y., Yang X., Yang H., Study on enrichment method of platinum, palladium and rhodium in spent auto-catalysts. Yejin Fenxi/Metallurgical Analysis. 2016, 36 (5), pp. 7-11.

8. Yoshimura A., Matsuno Y. Fundamental Study of Platinum Recovery from Spent AutoCatalyst Using "Dry Aqua Regia". Journal of the Japan Institute of Metals and Materials. 2019, 82 (3), pp. 164-171.

9. $\quad$ Ding Y., Zheng H., Li J., Zhang S., Liu B., Ekberg C., Jian Z. Recovery of Platinum from Spent Petroleum Catalysts: Optimization Using Response Surface Methodology. Metals. 2019, 9 (3), 354 .

10. T. Okada, Taniguchi Y., Nishimura F., Yonezawa S. Solubilization of palladium in molten mixture of sodium borates and sodium carbonate. Results in Physics. 2019, 13, 102281.

11. Dong H., Zhao J., Tong W., Cui H., Wu Y. Concentrating Pt from a spent alumina carrier catalyst by a roast-leach process. Metallurgical Research and Technology. 2019, 116 (2), 204.

12. Belov S.F., Igumnov M.S., Lovchinovsky I.Yu. Electrochemical method for processing of desactivated Al-Pd catalysts in fabrication of primary aluminium [In Russ]. Tsetnye metally. 1997, 5, pp. 46-48.

13. Belov S.F., Igumnov M.S., Lovchinovsky I.Yu. The influence of heat treatment on the phase composition of Al-Pd catalysts and leaching of palladium from them. Izvestiya VUZov. Tsvetnaya metallurgiya. 1985, 4, pp. 63-67

14. Belov S.F., Igumnov M.S., Lovchinovsky I.Yu. Electrochemical technique for processing of desactivated aluminium-palladium catalysts during fabrication of pure aluminium and palladium concentrate. Tsvetnye metally. 1997, 5, pp. 39-41. 
15. Polyakov P.V., Klyuchantsev A.B., Yasinskiy A.S. Popov Y.N. Conception of "Dream Cell" in aluminium electrolysis. TMS Light Metals. 2016, pp. 283-288

16. Padamata, S.K.; Yasinskiy, A.S., Polyakov, P.V. Electrolytes and its additives used in aluminium reduction cell: a review Metallurgical research \& technology. 2019, 116, (4), 410.

17. $\mathrm{Ru}$ Patent No 2689475, Apparatus for high purity aluminium production with carbon-free anodes and method of its implementation. Yasinskiy A.S., Polyakov P.V., Popov Yu.N., Polyakov A.A., Padamata S.K., applied 12.07.2018, published 28.05.2019, bull No 16.

18. Yasinskiy A.S., Padamata S.K., Polyakov P.V., Vinogradov O.O. Anodic process on aluminium bronze in low-temperature cryolite-alumina melts and suspensions. Tsvetnye Metally. 2019, vol. 9, In press.

19. Yasinskiy A.S., Padamata S.K., Polyakov P.V., Samoilo A.S., Suzdaltsev A.V., Nikolaev $\mathrm{A} . \mathrm{Yu}$. Electrochemical behaviour of $\mathrm{Cu}-\mathrm{Al}$ oxygen-evolving anodes in low-temperature fluoride melts and suspensions. Minerals, Metals and Materials Series: Light metals, 2020, in press.

20. Xu Y., Jiao H., Wang M., Jiao S. Direct preparation of V-Al alloy by molten salt electrolysis of soluble $\mathrm{NaVO}_{3}$ on a liquid Al cathode. Journal of Alloys and Compounds. 2019, 779, pp. 22-29.

21. Kan H., Wang Z., Wang X., Zhang N. Electrochemical deposition of aluminium on W electrode from $\mathrm{AlCl}_{3}-\mathrm{NaCl}$ melts. Transactions of Nonferrous Metals Society of China. 2010, 20, pp. $158-164$.

22. Nikolaev A.Yu., Suzdaltsev A.V., Zaikov Yu.P. Electrowinning of Aluminium and Scandium from KF-AlF $3-\mathrm{Sc}_{2} \mathrm{O}_{3}$ Melts for the Synthesis of Al-Sc Master Alloys. Journal of The Electrochemical Society. 2019, 166 (8), pp. D252-D257.

23. Filatov A.A., Pershin P.S., Suzdaltsev A.V., Nikolaev A.Yu., Zaikov Yu.P. Synthesis of

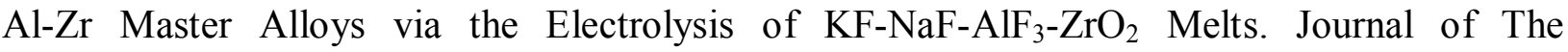
Electrochemical Society. 2018, 162 (2), pp. E28-E34.

24. Wei Z., Peng J., Wang Y., Liu K., Di Y., Sun T. Cathodic process of aluminium deposition in $\mathrm{NaF}-\mathrm{AlF}_{3}-\mathrm{Al}_{2} \mathrm{O}_{3}$ melts with low cryolite ratio. Ionics. 2019, 25(4), pp. 1735-1745.

25. Khramov A.P., Shurov N.I. Modern Views on the Composition of Anionic Oxy-Fluoride Complexes of Aluminium and Their Rearrangement during the Electrolysis of Cryolite-Alumina Melts. Russian Metallurgy (Metally). 2014, No. 8, pp. 581-592.

26. Nikolaev A.Yu., Suzdaltsev A.V., Polyakov P.V., Zaikov Yu.P. Cathode Process at the Electrolysis of $\mathrm{KF}-\mathrm{AlF}_{3}-\mathrm{Al}_{2} \mathrm{O}_{3}$ Melts and Suspensions. Journal of The Electrochemical Society. 2017, 164 (8), pp. H5315-H5321. 
27. Liu D., Yang Zh., Li W., Wang S., Wang Sh. Cathodic behavior of graphite in KF-AlF $3^{-}$ based melts with various cryolite ratios. Journal of Solid State Electrochemistry. 2011, 15, pp. $615-621$.

28. Liu D., Yang Zh., Li W.J. Electrochemical Behavior of Graphite in KF-AlF 3 -Based Melt with Low Cryolite Ratio. Journal of The Electrochemical Society. 2010, 157(7), pp. D417D421.

29. Janz G. J., Tomkins R. P. T., Allen C. B., Downey Jr. J. R., Garner G. L., Krebs U., Singer S. K. Molten salts: Volume 4, part 2, chlorides and mixtures-electrical conductance, density, viscosity, and surface tension data. Journal of Physical and Chemical Reference Data. 1975, 4, pp. 871-1178. 